\title{
Early changes in tissue amino acid metabolism and nutrient routing in rats fed a high-fat diet: evidence from natural isotope abundances of nitrogen and carbon in tissue proteins
}

\author{
Olivier L. Mantha ${ }^{1}$, Sergio Polakof ${ }^{2}$, Jean-François Huneau ${ }^{1}$, François Mariotti ${ }^{1}$, Nathalie Poupin ${ }^{3}$, \\ Daniel Zalko ${ }^{3}$ and Helene Fouillet ${ }^{1 *}$ \\ ${ }^{1}$ UMR PNCA, AgroParisTech, INRA, Université Paris-Saclay, 75005, Paris, France \\ ${ }^{2}$ Université Clermont Auvergne, INRA, UNH, Unité de Nutrition Humaine, CRNH Auvergne, Université Clermont Auvergne, \\ F-63000 Clermont-Ferrand, France \\ ${ }^{3}$ Toxalim (Research Centre in Food Toxicology), Université de Toulouse, INRA, ENVT, INP-Purpan, UPS, Toulouse, France \\ (Submitted 27 June 2017 - Final revision received 1 December 2017 - Accepted 7 January 2018 - First published online 5 March 2018)
}

\section{Abstract}

Little is known about how diet-induced obesity and insulin resistance affect protein and amino acid (AA) metabolism in tissues. The natural relative abundances of the heavy stable isotopes of $\mathrm{C}\left(\delta^{13} \mathrm{C}\right)$ and $\mathrm{N}\left(\delta^{15} \mathrm{~N}\right)$ in tissue proteins offer novel and promising biomarkers of AA metabolism. They, respectively, reflect the use of dietary macronutrients for tissue AA synthesis and the relative metabolic use of tissue AA for oxidation $v$. protein synthesis. In this study, $\delta^{13} \mathrm{C}$ and $\delta^{15} \mathrm{~N}$ were measured in the proteins of various tissues in young adult rats exposed perinatally and/or fed after weaning with a normal- or a high-fat (HF) diet, the aim being to characterise HF-induced tissue-specific changes in AA metabolism. HF feeding was shown to increase the routing of dietary fat to all tissue proteins via non-indispensable AA synthesis, but did not affect AA allocation between catabolic and anabolic processes in most tissues. However, the proportion of AA directed towards oxidation rather than protein synthesis was increased in the small intestine and decreased in the tibialis anterior muscle and adipose tissue. In adipose tissue, the AA reallocation was observed in the case of perinatal or post-weaning exposure to HF, whereas in the small intestine and tibialis anterior muscle the AA reallocation was only observed after HF exposure that covered both the perinatal and post-weaning periods. In conclusion, HF exposure induced an early reorganisation of AA metabolism involving tissue-specific effects, and in particular a decrease in the relative allocation of AA to oxidation in several peripheral tissues.

\section{Keywords: High-fat diets: ${ }^{13} \mathrm{C}$ and ${ }^{15} \mathrm{~N}$ natural isotope abundance: Dietary nutrient routing: Protein and amino acid metabolism:} Obesity: Insulin resistance

The consumption of high-energy diets rich in fat and sugars has increased worldwide, paralleling the worldwide rise in obesity and metabolic conditions such as type 2 diabetes mellitus and $\mathrm{CVD}^{(1,2)}$. Despite high inter-individual variability in sensitivity to gains in weight and adiposity under high-fat (HF) diets in both humans $^{(3-5)}$ and rodents ${ }^{(6,7)}$, HF over-feeding is known to favour the development of adiposity ${ }^{(8)}$ and metabolic disorders ${ }^{(9)}$ involving insulin resistance and ultimately leading to chronic diseases $^{(10,11)}$. Moreover, early perinatal HF exposure, by maternal HF nutrition during pregnancy and lactation, very likely contributes to the predisposition of offspring to HF-induced obesity and insulin resistance in later life $e^{(12-14)}$.

Although numerous studies have investigated how HF feeding affects carbohydrate and lipid metabolism, little is still known about its potential impact on protein and amino acid (AA) metabolism ${ }^{(15,16)}$. Several studies have shown that high plasma concentrations of several AA, including branched-chain
AA, are associated with obesity and the early onset of insulin resistance, as well as a higher risk of developing the metabolic syndrome or type 2 diabetes $^{(17-22)}$. Elevated circulating AA levels suggest an impaired metabolism, which may arise from either decreased AA catabolism and/or increased AA release as a result of increased protein degradation in some tissues, in line with the initiation of insulin resistance. However, the causes and underlying mechanisms are still poorly understood, and this is because of several reasons ${ }^{(17,18)}$. One reason is the diversity of the phenotypes reported with tissue-specific alterations in AA catabolism, with a modulation of catabolic enzyme activities being either similarly or oppositely altered, depending on the tissue ${ }^{(18,23)}$. The other reason is the unresolved debate about the possible alterations of the tissue kinetics of protein synthesis and degradation, with only few and conflicting findings about how these fluxes are affected by obesity and insulin resistance ${ }^{(15,16)}$. For instance, proteolysis

Abbreviations: AA, amino acid; $\mathrm{CHO}$, carbohydrate; $\mathrm{HF}$, high fat; NF, normal fat.

* Corresponding author: H. Fouillet, fax +33 1440818 58, email Helene.Fouillet@agroparistech.fr 
fluxes have mostly been measured at the whole-body level but seldom at the muscle level, with contradictory results, which generally reported no effects of obesity or insulin resistance, or in some cases a proteolysis increase at the whole-body level ${ }^{(24-26)}$ or a proteolysis decrease at the muscle level ${ }^{(27)}$. Such discrepancies probably reflect the limitations of classic tracer methods when investigating protein kinetics and their alterations ${ }^{(28)}$. In this context, new and alternative approaches are required in order to gain a more integrated insight into the partitioning and potential reallocation of AA between different anabolic and catabolic fluxes in tissues, so as to ultimately decipher the effects of obesity and insulin resistance on AA and protein metabolism.

To this end, the natural abundances of stable $\mathrm{N}$ isotopes in tissue proteins constitute new, relevant and promising biomarkers of AA metabolism in tissues. Dietary protein $\mathrm{N}$ is the sole source of body protein $\mathrm{N}$, but body proteins are naturally enriched in the heavier stable $\mathrm{N}$ isotope $\left({ }^{15} \mathrm{~N}\right)$ over dietary protein. This ${ }^{15} \mathrm{~N}$ bioaccumulation $\left(\Delta^{15} \mathrm{~N}\right.$, also known as the trophic step or discrimination factor) is globally due to discrimination against this heavy isotope during $\mathrm{N}$ waste formation and particularly during urea production ${ }^{(29-31)}$. More precisely, $\Delta^{15} \mathrm{~N}$ values vary among tissues as a result of differences in AA composition ${ }^{(32)}$, but also and mostly as a result of the particular AA metabolism in the tissue, because of the existence of several isotope effects associated with different metabolic pathways such as AA oxidation, as well as protein turnover in tissues ${ }^{(31,33)}$. Consequently, variations in different body fluxes of the catabolic or anabolic use of AA can result in $\Delta^{15} \mathrm{~N}$ variations, and tissue $\Delta^{15} \mathrm{~N}$ measurements are integrative biomarkers for the tissue-specific metabolic impact of nutritional and/or physiopathological conditions. For instance, in humans, variations in hair ${ }^{15} \mathrm{~N}$ natural abundance values have been shown to reflect changes in $\mathrm{N}$ metabolism during pregnancy ${ }^{(34)}$, nutritional stress ${ }^{(35)}$, anorexia ${ }^{(36,37)}$ and cirrhosis ${ }^{(38)}$, and $\Delta^{15} \mathrm{~N}$ values in some animal tissues have been shown to reflect dietary protein quality and anabolic use efficiency $^{(29,30,33,39-41)}$. More precisely, we have previously shown, by analysing simultaneous multi-tissue $\Delta^{15} \mathrm{~N}$ measurements using a multi-compartment model, that tissue protein $\Delta^{15} \mathrm{~N}$ values constitute integrated and interpretable biomarkers of tissue AA partitioning between protein synthesis and oxidation ${ }^{(31)}$

In addition, the natural abundances of stable $\mathrm{C}$ isotopes in tissue proteins are also informative about the dietary origin of tissue AA. In contrast with $\mathrm{N}$, the heavier, stable $\mathrm{C}$ isotope $\left({ }^{13} \mathrm{C}\right)$ only modestly bioaccumulates ${ }^{(32,42)}$, and if the $\mathrm{C}$ found in tissue proteins preferentially originates from dietary proteins it can also derive from dietary lipids and carbohydrates $(\mathrm{CHO})$ that are used for non-indispensable AA synthesis ${ }^{(43-46)}$. Because dietary macronutrients generally differ in their natural ${ }^{13} \mathrm{C}$ abundances, those in tissue proteins may reflect macronutrient use for $\mathrm{AA}$ synthesis and consequent routing to tissue proteins, which can vary in line with nutritional and physiopathological conditions ${ }^{(36,43,44,46-49)}$.

In this study, we used these new $\mathrm{C}$ and $\mathrm{N}$ isotopic biomarkers in order to better characterise the tissue-specific dysregulations of AA metabolism induced by exposure to an HF diet. C isotopic values were used as indicators of the relative utilisation of dietary macronutrients for tissue AA synthesis, and $\mathrm{N}$ isotopic values as indicators for the preferential metabolic use of tissue
AA for anabolic $v$. catabolic purposes. The study was carried out in rats exposed to an HF diet during the perinatal and/or postweaning periods, as a model of early exposure to HF that is known to increase the risk for obesity and insulin resistance.

\section{Methods}

\section{Animals and diets}

The animal protocol formed part of a larger study designed to explore the combined effects of diet and exposure to contaminants, whose initial results have already been presented at the 9th Copenhagen Workshop on Endocrine Disrupters COW $2017^{(50)}$. In this ancillary study, specific tissues were sampled for isotopic analyses of a subset of animals. SpragueDawley dams were pair-fed either a normal-fat (NF) or HF diet during gestation and lactation, from gestational day 8 onwards, while maintaining an equal $\mathrm{N}$ intake. After weaning, from postnatal day 21 onwards, male pups were pair-fed with either the NF or HF diet to include all combinations of perinatal and post-weaning dietary exposures (NF-NF, $n$ 9; NF-HF, $n$ 7; HF-NF, $n$ 8; HF-HF, $n$ 8). Dietary macronutrient compositions were adjusted daily according to the recommendations of Reeves et $a l^{(51)}$ in order to meet the protein and lipid requirements of gestation, lactation and early postnatal growth. The macronutrient composition of the diets following the stabilisation of food intake (from postnatal day 35 ) is detailed in Table 1. Compared with the NF diet, the HF diet had the same protein content (16.7 wt \%), a higher lipid content (35 v. $6 \mathrm{wt} \%$ ) owing to $\mathrm{CHO}$ substitution and a different $\mathrm{CHO}$ profile $(67 \%$ maltodextrin and 33\% sucrose v. 100\% maltodextrin) for its potential effect on obesity and insulin resistance. Food intake was measured daily throughout the study. On postnatal day 115 , the body composition of the animals was measured using NMR-MRI-based technology (EchoMRI ${ }^{\mathrm{TM}}$ 700) and oral glucose tolerance tests (OGTT) were performed in order to determine insulin sensitivity. In brief, a glucose bolus $(1 \mathrm{~g} / \mathrm{kg})$ was

Table 1. Nutrient and isotopic compositions of normal- and high-fat diets

\begin{tabular}{|c|c|c|}
\hline & Normal fat & High fat \\
\hline \multicolumn{3}{|l|}{ Nutrients (wt\%) } \\
\hline Protein & $16 \cdot 7$ & $16 \cdot 7$ \\
\hline Carbohydrates & $67 \cdot 7^{\star}$ & $38.7 \dagger$ \\
\hline Lipids & $6 \cdot 0$ & $35 \cdot 0$ \\
\hline Fibre & $5 \cdot 0$ & $5 \cdot 0$ \\
\hline Minerals & 3.5 & 3.5 \\
\hline Vitamins & $1 \cdot 1$ & $1 \cdot 1$ \\
\hline \multicolumn{3}{|l|}{$\begin{array}{l}\text { Isotopes (\%o) } \\
\delta^{15} \mathrm{~N}\end{array}$} \\
\hline $\begin{array}{l}\text { Protein } \\
\delta^{13} \mathrm{C}\end{array}$ & $6 \cdot 1$ & $6 \cdot 1$ \\
\hline Protein & $-22 \cdot 2$ & $-22 \cdot 2$ \\
\hline Carbohydrates & $-11 \cdot 3^{\star}$ & $-16 \cdot 3 \dagger$ \\
\hline Lipids & $-30 \cdot 4$ & $-30 \cdot 4$ \\
\hline Energył & $-13 \cdot 8$ & $-23 \cdot 0$ \\
\hline
\end{tabular}


administered orally after an overnight fast, and blood samples were taken from the tail vein before and 15, 30, 60 and $120 \mathrm{~min}$ after glucose administration. The blood glucose (OneTouch Ultra Easy glucometer; LifeScan) area under the concentrationtime curve (AUC) was calculated using the trapezoid method. The rats were euthanised under pentobarbital anaesthesia on postnatal day 120 after an overnight fast. After an abdominal incision, blood was drawn from the abdominal aorta using a citrate-coated syringe. After centrifugation (12000 g, 2 min), plasma and erythrocytes were rapidly aliquoted, frozen in liquid $\mathrm{N}_{2}$ and stored at $-80^{\circ} \mathrm{C}$. Plasma insulin levels were measured by ELISA (Millipore). Different tissues were also rapidly collected (liver, small intestine, heart; tibialis anterior, gastrocnemius, soleus and extensor digitorum longus muscles; and subcutaneous adipose tissue), weighed, freeze-clamped in liquid $\mathrm{N}_{2}$ and stored at $-80^{\circ} \mathrm{C}$ until further analyses. Faeces were also collected and stored under the same conditions. The animals were handled according to the recommendations of the Regional Ethics Committee (accreditation number issued by the Ministry for Research: 00837·01).

\section{Feed efficiency and liver protein anabolism efficiency}

Feed efficiency was defined as the ratio of body weight at postnatal day 120 relative to cumulative food intake. Liver samples were homogenised and centrifuged (20000 g, $10 \mathrm{~min})$ and the protein content was measured using a bicinchoninic acid assay kit (Bio-Rad). Liver protein anabolism efficiency (\%) was defined as the ratio of liver protein content at the time of killing relative to cumulative protein intake over the postweaning period

\section{Tissue protein extraction}

Frozen tissues were cooled with liquid $\mathrm{N}_{2}$ and pulverised with a pestle and mortar. Tissue proteins were precipitated from pulverised tissues $(100 \mathrm{mg})$ with 5 -sulfosalicylic acid $(10 \%$, $7 \mu \mathrm{l} / \mathrm{mg}$ of tissue). Twice, after centrifugation $\left(10000 \mathrm{~g}, 4^{\circ} \mathrm{C}\right.$, $20 \mathrm{~min}$ ), the supernatant was removed and the protein pellets were washed with 5-sulfosalicylic acid (10\%) and freeze-dried. Subcutaneous adipose tissue ( $1 \mathrm{~g})$ was first homogenised in $0.9 \% \mathrm{NaCl}$ using an Ultra-Turrax homogenizer (T25 digital; IKA). After centrifugation $\left(2000 \mathrm{~g}, 2^{\circ} \mathrm{C}, 20 \mathrm{~min}\right)$, the infranatant containing the proteins was collected using a syringe and needle, and the floating fat layer containing the lipids was stored at $-20^{\circ} \mathrm{C}$ until isotopic analysis. Adipose tissue proteins were further precipitated with $100 \mu \mathrm{l}$ of 5-sulfosalicylic acid (100\%) and thereafter treated as described for other tissues. Plasma proteins were precipitated from $0.5 \mathrm{ml}$ of plasma with 5 -sulfosalicylic acid ( $100 \%, 50 \mu \mathrm{l} / \mathrm{ml}$ of plasma) and the samples were centrifuged $\left(2000 \mathrm{~g}, 4^{\circ} \mathrm{C}, 20 \mathrm{~min}\right)$ after $1 \mathrm{~h}$ of incubation at $4^{\circ} \mathrm{C}$. The supernatant was removed and the protein pellets were washed with $\mathrm{H}_{2} \mathrm{O}$, centrifuged again as described above and freeze-dried. The protein pellets from all matrices were delipidated using 1:1 ethanol-diethyl ether. Twice, the proteins were mixed for $1 \mathrm{~h}$ with the solvent mixture using a tube rotator and the supernatant was removed after a brief centrifugation $(1000 \mathrm{~g}$, $\left.20^{\circ} \mathrm{C}, 5 \mathrm{~min}\right)$. The remaining solvents were eliminated by centrifugal evaporation. The faeces were freeze-dried and pulverised, and then the resulting powder was analysed without any further treatment.

\section{Isotopic analysis}

The natural abundances of $\mathrm{N}$ and $\mathrm{C}$ stable isotopes in samples were expressed relative to standards (atmospheric $\mathrm{N}_{2}$ for ${ }^{15} \mathrm{~N} /{ }^{14} \mathrm{~N}$ and Vienna Pee Dee Belemnite for ${ }^{13} \mathrm{C} /{ }^{12} \mathrm{C}$, respectively) using the delta notation:

$$
\delta(\% 0)=1000 \times\left(R_{\text {sample }}-R_{\text {standard }}\right) / R_{\text {standard }},
$$

where $\delta$ is the parts-per-thousand difference in ratio of heavy to light isotopes $\left({ }^{15} \mathrm{~N} /{ }^{14} \mathrm{~N}\right.$ and $\left.{ }^{13} \mathrm{C} /{ }^{12} \mathrm{C}\right)$ in the samples $\left(R_{\text {sample }}\right)$ and standards ( $R_{\text {standard }}, 0.0112372$ for $\mathrm{C}$ and 0.0036765 for $\mathrm{N}$ ). We measured $\delta^{15} \mathrm{~N}$ and $\delta^{13} \mathrm{C}$ in the proteins in the different tissues sampled, in the faeces, in lipids from adipose tissue and in dietary proteins, $\mathrm{CHO}$ and lipids. Isotopic measurements were performed with an isotope-ratio mass spectrometer (Isoprime; VG Instruments) coupled to an elemental analyser (EA Vario Micro Cube; Elementar). Tyrosine was used for calibration and drift correction. $\delta^{15} \mathrm{~N}$ and $\delta^{13} \mathrm{C}$ values for tissue proteins and faeces were expressed relative to the $\delta$ value of dietary proteins using the capital delta notation $\left(\Delta_{\text {tissue }}\right.$ proteins $=\delta_{\text {tissue proteins }}-\delta_{\text {dietary }}$ proteins). The $\delta^{13} \mathrm{C}$ of adipose tissue lipids was similarly expressed but relative to dietary lipid $\delta^{13} \mathrm{C}$. For each diet, $\delta^{13} \mathrm{C}$ of non-protein energy sources was calculated as the average $\delta^{13} \mathrm{C}$ of lipids and $\mathrm{CHO}$ weighted by their $\mathrm{C}$ content and dietary occurrence as follows ${ }^{(43,44)}$ :

$$
\begin{aligned}
\delta^{13} \mathrm{C}_{\mathrm{E}}= & {\left[\left(\%_{\mathrm{C}} \times 0.444\right) /\left(\%_{\mathrm{L}} \times 0.768+\%_{\mathrm{C}} \times 0.444\right)\right] \times \delta^{13} \mathrm{C}_{\mathrm{C}} } \\
& +\left[\left(\%_{\mathrm{L}} \times 0.768\right) /\left(\%_{\mathrm{L}} \times 0.768+\%_{\mathrm{C}} \times 0.444\right)\right] \times \delta^{13} \mathrm{C}_{\mathrm{L}},
\end{aligned}
$$

where $\delta^{13} \mathrm{C}_{\mathrm{C}}, \delta^{13} \mathrm{C}_{\mathrm{L}}$ and $\delta^{13} \mathrm{C}_{\mathrm{E}}$ are, respectively, the $\delta^{13} \mathrm{C}$ values of dietary lipids, $\mathrm{CHO}$ and non-protein energy sources, $\%_{\mathrm{C}}$ and $\%_{\mathrm{L}}$ are dietary mass fractions of $\mathrm{CHO}$ and lipids and 0.444 and 0.768 are the reference $\mathrm{C}$ mass fractions of $\mathrm{CHO}$ and lipids, respectively.

\section{Assessment of the contribution of dietary macronutrients to amino acid synthesis}

The $\mathrm{C}$ in tissue proteins has various origins. Indeed, even though dietary proteins are preferentially routed to tissue proteins as AA, dietary lipids and $\mathrm{CHO}$ are used for the biosynthesis of non-indispensable AA and thus routed to protein synthesis, the degree of which varies according to the dietary macronutrient content ${ }^{(43,44,46)}$. Therefore, by hypothesising an isotopic steady state owing to the entire renewal of tissue proteins since weaning, the $\delta^{13} \mathrm{C}$ of tissue proteins represents the sum of dietary macronutrient $\delta^{13} \mathrm{C}$ values weighted by their respective contributions to $\mathrm{C}$ in tissue proteins (routing coefficients), in addition to the difference in $\delta^{13} \mathrm{C}$ between diet and tissue proteins because of isotopic fractionation along metabolic pathways (the trophic step). In our study, the three dietary macronutrients differed in terms of their $\delta^{13} \mathrm{C}$ and the two diets in terms of their $\delta^{13} \mathrm{C}_{\mathrm{E}}$, because of the different $\mathrm{CHO}$ and lipid contents (Table 1). These $\delta^{13} \mathrm{C}$ signatures of macronutrients and diets allowed us to estimate the routing coefficients for each macronutrient and diet. 
In a first step, the contributions of dietary proteins were derived from the following equation:

$$
\begin{aligned}
\delta^{13} \mathrm{C}_{\mathrm{T}_{\mathrm{d}}} & =p_{\mathrm{d}} \times\left(\delta^{13} \mathrm{C}_{\mathrm{P}}+\mathrm{TS}_{\mathrm{P}}\right)+\left(1-p_{\mathrm{d}}\right) \times\left(\delta^{13} \mathrm{C}_{\mathrm{E}_{\mathrm{d}}}+\mathrm{TS}_{\mathrm{E}_{\mathrm{d}}}\right) \\
& =p_{\mathrm{d}} \times \delta^{13} \mathrm{C}_{\mathrm{P}}+\left(1-p_{\mathrm{d}}\right) \times \delta^{13} \mathrm{C}_{\mathrm{E}_{\mathrm{d}}}+\mathrm{TS}_{\mathrm{d}},
\end{aligned}
$$

where $\delta^{13} \mathrm{C}_{\mathrm{T}_{\mathrm{d}}}, \delta^{13} \mathrm{C}_{\mathrm{P}}$ and $\delta^{13} \mathrm{C}_{\mathrm{E}_{\mathrm{d}}}$ are, respectively, the $\delta^{13} \mathrm{C}$ values of proteins in a tissue, of dietary proteins and of dietary nonprotein energy sources in the post-weaning diet $d(d=N F$ or $\mathrm{HF}$ ). $p_{\mathrm{d}}$ and $1-p_{\mathrm{d}}$ are the proportions of protein and nonprotein dietary macronutrients routed to $\mathrm{C}$ in tissue proteins (the protein and energy routing coefficients, respectively). $\mathrm{TS}_{\mathrm{P}}$ and $\mathrm{TS}_{\mathrm{E}_{\mathrm{d}}}$ are the specific trophic steps on dietary protein and energy, and $\mathrm{TS}_{\mathrm{d}}$ is the global trophic step $\left(\mathrm{TS}_{\mathrm{d}}=p_{\mathrm{d}} \times \mathrm{TS}_{\mathrm{P}}+\right.$ $\left(1-p_{\mathrm{d}}\right) \mathrm{TS}_{\mathrm{E}_{\mathrm{d}}}$. To solve Equation (3), $p$ and TS were assumed to be equal across our diets having an identical and adequate protein content, as $p$ and TS have previously been shown to be extremely consistent over a spectrum of dietary compositions, except for deficient or excessive protein contents ${ }^{(43)}$. By solving Equation (3) simultaneously for each post-weaning diet (NF and $\mathrm{HF})$, we obtained an identifiable system of two linear equations and two unknowns, $p$ and TS, whose solution was as follows:

$$
\begin{gathered}
p=\left(\delta^{13} \mathrm{C}_{\mathrm{E}_{\mathrm{NF}}}-\delta^{13} \mathrm{C}_{\mathrm{E}_{\mathrm{HF}}}+\delta^{13} \mathrm{C}_{\mathrm{T}_{\mathrm{HF}}}-\delta^{13} \mathrm{C}_{\mathrm{T}_{\mathrm{NF}}}\right) / \\
\mathrm{TS}=\left(\delta^{13} \mathrm{C}_{\mathrm{E}_{\mathrm{NF}}}-\delta^{13} \mathrm{C}_{\mathrm{T}_{\mathrm{NF}}}-\delta^{13} \mathrm{C}_{\mathrm{E}_{\mathrm{NF}}}\right)-\left(\delta^{13} \mathrm{C}_{\mathrm{E}_{\mathrm{NF}}}-\delta^{13} \mathrm{C}_{\mathrm{E}_{\mathrm{HF}}}+\delta^{13} \mathrm{C}_{\mathrm{T}_{\mathrm{HF}}}-\delta^{13} \mathrm{C}_{\mathrm{T}_{\mathrm{NF}}}\right) \\
\times\left(\delta^{13} \mathrm{C}_{\mathrm{P}}-\delta^{13} \mathrm{C}_{\mathrm{E}_{\mathrm{NF}}}\right) /\left(\delta^{13} \mathrm{C}_{\mathrm{E}_{\mathrm{NF}}}-\delta^{13} \mathrm{C}_{\mathrm{E}_{\mathrm{HF}}}\right) .
\end{gathered}
$$

The contributions of dietary $\mathrm{CHO}$ and lipids to $\mathrm{C}$ in tissue proteins were then estimated using the following equation:

$$
\delta^{13} \mathrm{C}_{\mathrm{T}_{\mathrm{d}}}=p \times \delta^{13} \mathrm{C}_{\mathrm{P}}+c_{\mathrm{d}} \times \delta^{13} \mathrm{C}_{\mathrm{C}_{\mathrm{d}}}+\left(1-p-c_{\mathrm{d}}\right) \times \delta^{13} \mathrm{C}_{\mathrm{L}}+\mathrm{TS} .
$$

Here, $\mathrm{c}_{\mathrm{d}}$ and $1-p-c_{\mathrm{d}}$ are the proportions of $\mathrm{CHO}$ and lipids routed, respectively, to $\mathrm{C}$ in tissue proteins (the $\mathrm{CHO}$ and lipid routing coefficients) and $\delta^{13} \mathrm{C}_{C_{\mathrm{d}}}$ and $\delta^{13} \mathrm{C}_{\mathrm{L}}$ are their respective $\delta^{13} \mathrm{C}$ values in diet d. Equation (6) was solved for $c_{\mathrm{d}}$ as follows:

$$
\begin{aligned}
c_{\mathrm{NF}}= & {\left[\delta^{13} \mathrm{C}_{\mathrm{T}_{\mathrm{NF}}}-\delta^{13} \mathrm{C}_{\mathrm{L}}-\mathrm{TS}+p \times\left(\delta^{13} \mathrm{C}_{\mathrm{L}}-\delta^{13} \mathrm{C}_{\mathrm{P}}\right)\right] / } \\
& \left(\delta^{13} \mathrm{C}_{C_{\mathrm{NF}}}-\delta^{13} \mathrm{C}_{\mathrm{L}}\right) . \\
c_{\mathrm{HF}}= & {\left[\delta^{13} \mathrm{C}_{\mathrm{T}_{\mathrm{HF}}}-\delta^{13} \mathrm{C}_{\mathrm{L}}-\mathrm{TS}+p \times\left(\delta^{13} \mathrm{C}_{\mathrm{L}}-\delta^{13} \mathrm{C}_{\mathrm{P}}\right)\right] / } \\
& \left(\delta^{13} \mathrm{C}_{\mathrm{C}_{\mathrm{HF}}}-\delta^{13} \mathrm{C}_{\mathrm{L}}\right) .
\end{aligned}
$$

\section{Assessment of tissue amino acid allocation between anabolic and catabolic pathways}

We had previously investigated the causes and significance of $\Delta^{15} \mathrm{~N}$ variations across tissues and diets using a multicompartmental analysis of multi-tissue $\Delta^{15} \mathrm{~N}$ measurements in rats, and showed that the $\Delta^{15} \mathrm{~N}$ of a tissue protein varies as a function of $\mathrm{p}_{\mathrm{ox}}$, the proportion of tissue AA that is directed towards oxidation rather than used for protein synthesis ${ }^{(31)}$. In particular, according to model predictions, a rise in $\Delta^{15} \mathrm{~N}$ levels indicates an increase in $p_{o x}$ in all tissues except muscle, where in contrast it is indicative of a reduction in $\mathrm{p}_{\mathrm{ox}}$ because of its opposite sign of isotopic fractionation associated with AA catabolism. Indeed, in most tissues, AA losses for catabolic purposes favour ${ }^{14} \mathrm{~N}$ elimination and hence ${ }^{15} \mathrm{~N}$ retention owing to the isotope effects associated with transamination and liver deamination, whereas under catabolic conditions muscle releases some of the most ${ }^{15} \mathrm{~N}$-enriched AA (such as Ala and Gln) into the bloodstream, which may favour ${ }^{15} \mathrm{~N}$ elimination from the muscle as previously discussed $^{(31)}$. Our model prediction for the $\Delta^{15} \mathrm{~N}$ and $\mathrm{p}_{\mathrm{ox}}$ relationships in splanchnic tissues was further validated experimentally by combining AA tracers and arteriovenous balance methods in ruminants, where we showed that the $\Delta^{15} \mathrm{~N}$ of plasma proteins, which are synthesised in the splanchnic bed and mainly in liver, linearly increases with the splanchnic AA metabolism and oxidation and the liver urea production ${ }^{(29)}$. In the present study, the observed diet-induced $\Delta^{15} \mathrm{~N}$ variations were interpreted in the light of these previous modelling ${ }^{(31)}$ and experimental ${ }^{(29)}$ results: a higher $\Delta^{15} \mathrm{~N}$ was interpreted as indicative of an higher $\mathrm{p}_{\mathrm{ox}}$ in all tissues except the muscle, where it was interpreted as indicative of a lower $p_{o x}$.

\section{Statistical analyses}

Because this was an ancillary study during which thirty-two animals received the four dietary treatments studied here, the sample size was fixed. However, we reasoned that the study would be powerful enough with eight rats in each group, because this sample size allowed minimally detectable effect sizes of $0.3 \%$ using a $t$ test on group means for both $\Delta^{15} \mathrm{~N}$ and $\Delta^{13} \mathrm{C}$ values, assuming a level of significance of 0.05 , a power level of 0.80 and a standard deviation of $0.2 \%{ }^{(52)}$. Such a $0.3 \%$ effect size was small enough to enable the detection of diet-induced changes in (i) tissue AA metabolism using $\Delta^{15} \mathrm{~N}$ values, according to our previous model predictions ${ }^{(31)}$, and (ii) nutrient routing to tissue protein using $\Delta^{13} \mathrm{C}$ values, because $0.3 \%$ is $<2 \%$ of the difference between dietary $\mathrm{CHO}$ and lipid $\Delta^{13} \mathrm{C}$ values.

ANOVA using Tukey's post hoc test was run under SAS (version 21) in order to determine differences between the groups in terms of body composition, metabolic parameters and $\Delta^{15} \mathrm{~N}$ and $\Delta^{13} \mathrm{C}$ values $(\alpha=0 \cdot 05)$. Pearson's correlation coefficients between $\Delta^{15} \mathrm{~N}$ and metabolic and body composition parameters of interest were evaluated for their significance using the Benjamini-Hochberg false discovery rate $(\mathrm{FDR})^{(53)}$. The FDR correction was used to control the rate of false discoveries among significant correlations, and correlations with an $\mathrm{FDR} \leq 15 \%$ were considered as significant. The data are expressed as means and standard deviations.

\section{Results}

\section{Body composition, insulin sensitivity and feed efficiency}

Post-weaning nutrition was the only factor that affected the body composition and metabolic parameters of the animals. Compared with the NF post-weaning diet, the HF post-weaning diet (i.e. NF-HF and HF-HF $v$. NF-NF and HF-NF) induced a higher body weight $(+28 \%, 529$ (SD 50) v. 412 (sD 27) g, $P<0 \cdot 0001)$, with a higher fat mass $(+178 \%, 121$ (sD 38) v. 44 (sD 16) g, $P<0.0001)$ and a higher lean mass $(+10 \%, 354$ (SD 33) v. 322 (SD 36) g, $P<0.05)$. The following metabolic parameters were also 
increased under the HF post-weaning diet: plasma insulin levels $(+100 \%, 74.8$ (sD 48.6) v. 37.5 (sD 12.3) pM, $P<0.01$ ), glucose OGTT AUC (+19\%, 824 (SD 105) v. 695 (SD 54) $\mathrm{mM} \times 120 \mathrm{~min}$, $P<0.01$ ), feed efficiency $(+27 \%, 66.4$ (sD 4.8) v. 52.2 (sD 3.4)\%, $P<0.0001)$ and liver protein anabolism efficiency $(+18 \%, 1.98$ (sD 0.45) v. 1.69 (sD 0.16) \%, $P<0.05$ ).

\section{Natural abundances of stable carbon isotopes $\left(\Delta^{13} C\right)$ in tissue proteins and dietary macronutrient use for amino acid synthesis}

Only post-weaning nutrition affected $\Delta^{13} \mathrm{C}$ values in tissue proteins, faeces and adipose tissue lipids, as presented in Table $2 . \Delta^{13} \mathrm{C}$ values after HF post-weaning feeding were lower in all the pools sampled, regardless of perinatal nutrition (NF-HF and HF-HF were lower than NF-NF and HF-NF, all $P<0.0001$ ). This indicates a more marked routing of dietary lipids, the macronutrient with the lowest $\delta^{13} \mathrm{C}$, to adipose tissue lipids and tissue proteins when the animals consumed the HF diet.
Given the lack of effects of perinatal nutrition on $\Delta^{13} \mathrm{C}$ values, the contributions of dietary macronutrients (protein, $\mathrm{CHO}$ and lipid) to $\mathrm{C}$ in tissue proteins (i.e. nutrient routing) were calculated for post-weaning diets only (HF: $n$ 15, NF: $n$ 17), for each sampled tissue (intestine, liver, plasma, erythrocytes, heart and four muscles). In each tissue, for identifiability reasons, protein routing (but not $\mathrm{CHO}$ and lipid routings) was assumed to be equal across the diets given their identical protein (but not energy) content. These nutrient routing results are presented in Table 3 (mean values across tissues) and in online Supplementary Table S2 (values for each tissue). For all tissues, proteins were preferentially sourced from dietary proteins, with protein routing that averaged $74 \cdot 2$ (SD 2.4 ) \% across the tissues (Table 3). The routing of $\mathrm{CHO}$ and lipids was found to be largely dependent on diet, with a higher routing of lipid under HF feeding, but overall a higher routing of $\mathrm{CHO}$ than lipid for all tissues and diets. On average, in all the tissues sampled, lipid routing indeed reached $3 \cdot 4$ (SD 0.3) \% and $12 \cdot 1$ (SD $1 \cdot 1$ ) \% with the NF and HF diets, respectively, whereas $\mathrm{CHO}$

Table 2. Natural abundances of carbon stable isotopes in tissue proteins, faeces and adipose tissue lipids $\left(\Delta^{13} \mathrm{C}\right)^{*}$ (Mean values and standard deviations)

\begin{tabular}{|c|c|c|c|c|c|c|c|c|c|c|c|}
\hline & \multicolumn{2}{|c|}{ NF-NF } & \multicolumn{2}{|c|}{ HF-NF } & \multicolumn{2}{|c|}{$\mathrm{NF}-\mathrm{HF}$} & \multicolumn{2}{|c|}{$\mathrm{HF}-\mathrm{HF}$} & \multicolumn{3}{|c|}{$P$} \\
\hline & Mean & SD & Mean & SD & Mean & SD & Mean & SD & Peri & Post & Peri $\times$ Post \\
\hline$n$ & \multicolumn{2}{|c|}{9} & \multicolumn{2}{|c|}{8} & \multicolumn{2}{|c|}{7} & \multicolumn{2}{|c|}{8} & & & \\
\hline Protein $\Delta^{13} \mathrm{C}(\%)$ & & & & & & & & & & & \\
\hline Small intestine & $2 \cdot 8^{\mathrm{a}}$ & 0.1 & $2 \cdot 9^{a}$ & $0 \cdot 1$ & $0.4^{\mathrm{b}}$ & 0.1 & $0.5^{\mathrm{b}}$ & 0.1 & & $<0.0001$ & \\
\hline Liver & $3 \cdot 2^{\mathrm{a}}$ & 0.2 & $3 \cdot 2^{\mathrm{a}}$ & 0.1 & $0.8^{\mathrm{b}}$ & 0.1 & $0.8^{\mathrm{b}}$ & 0.2 & & $<0.0001$ & \\
\hline AT & $2 \cdot 9^{a}$ & 0.2 & $3.0^{a}$ & 0.2 & $0.7^{\mathrm{b}}$ & 0.1 & $0.7^{b}$ & 0.1 & & $<0.0001$ & \\
\hline TA muscle & $2 \cdot 8^{\mathrm{a}}$ & 0.2 & $2 \cdot 8^{\mathrm{a}}$ & 0.2 & $0.4^{\mathrm{b}}$ & 0.2 & $0.4^{b}$ & 0.1 & & $<0.0001$ & \\
\hline G muscle & $2 \cdot 8^{a}$ & 0.3 & $2 \cdot 6^{a}$ & 0.2 & $0.4^{\mathrm{b}}$ & 0.1 & $0.3^{\mathrm{b}}$ & 0.2 & & $<0.0001$ & \\
\hline EDL muscle & $2 \cdot 8^{a}$ & 0.2 & $2 \cdot 9^{a}$ & 0.3 & $0.5^{\mathrm{b}}$ & 0.3 & $0.8^{\mathrm{b}}$ & 0.3 & & $<0.0001$ & \\
\hline S muscle & $2 \cdot 9^{\mathrm{a}}$ & 0.2 & $2 \cdot 9^{a}$ & 0.1 & $0.3^{\mathrm{b}}$ & 0.1 & $0.3^{\mathrm{b}}$ & 0.1 & & $<0.0001$ & \\
\hline Heart & $2 \cdot 9^{\mathrm{a}}$ & 0.1 & $2 \cdot 6^{\mathrm{a}}$ & 0.2 & $0.3^{\mathrm{b}}$ & 0.2 & $0.4^{\mathrm{b}}$ & 0.1 & & $<0.0001$ & $<0.01$ \\
\hline Plasma & $3.3^{\mathrm{a}}$ & 0.1 & $3 \cdot 2^{a}$ & 0.1 & $0.7^{\mathrm{b}}$ & 0.1 & $0.6^{\mathrm{b}}$ & 0.1 & & $<0.0001$ & \\
\hline Erythrocytes & $1 \cdot 8^{a}$ & 0.1 & $1 \cdot 8^{\mathrm{a}}$ & 0.2 & $0.0^{\mathrm{b}}$ & 0.1 & $-0.1^{\mathrm{b}}$ & 0.1 & & $<0.0001$ & \\
\hline Faeces $\Delta{ }^{13} \mathrm{C}(\%)$ & $-3 \cdot 3^{a}$ & 0.6 & $-3 \cdot 7^{a}$ & 0.3 & $-5 \cdot 3^{b}$ & 0.2 & $-5 \cdot 3^{b}$ & 0.4 & & $<0.0001$ & \\
\hline AT lipid $\Delta^{13} \mathrm{C}(\%)$ & $8 \cdot 5^{\mathrm{a}}$ & 0.9 & $8 \cdot 6^{a}$ & 0.7 & $1.5^{\mathrm{b}}$ & 0.1 & $1.6^{\mathrm{b}}$ & 0.1 & & $<0.0001$ & \\
\hline
\end{tabular}

NF-NF, rats exposed to the normal-fat (NF) diet during the perinatal and post-weaning periods; NF-HF, rats exposed to the NF diet during the perinatal period and the high-fat (HF) diet during the post-weaning period; HF-NF, rats exposed to the HF diet during the perinatal period and the NF diet during the post-weaning period; HF-HF, rats exposed to the HF diet during both the perinatal and post-weaning periods; peri, perinatal diet; post, post-weaning diet; AT, adipose tissue; TA, tibialis anterior, G, gastronemius; EDL, extensor digitorum longus; S, soleus.

a,b Mean values with unlike superscript letters were significantly different between groups $(P<0.0001)$.

${ }^{*}$ Protein and faeces $\Delta^{13} \mathrm{C}$ values are the differences between protein or faeces $\delta^{13} \mathrm{C}$ and dietary protein $\delta^{13} \mathrm{C}$. AT Lipid $\Delta^{13} \mathrm{C}$ is the difference between AT lipid $\delta^{13} \mathrm{C}$ and dietary lipid $\delta^{13} \mathrm{C}$.

Table 3. Routing coefficients of dietary macronutrients to tissue proteins in rats fed a normal- or high-fat diet (Mean values and standard deviations and minimum and maximum values across tissues)

\begin{tabular}{|c|c|c|c|c|c|c|}
\hline & \multicolumn{3}{|c|}{ Normal fat } & \multicolumn{3}{|c|}{ High fat } \\
\hline & Mean & SD & Min-max & Mean & SD & Min-max \\
\hline Trophic step (\%o) & \multicolumn{6}{|c|}{$0.63(\mathrm{sD} 0.25)(\min -\max 0.12-0.99)$} \\
\hline Protein routing (\%) & & & 74.2 (SD 2.4 & $71 \cdot 8-7$ & & \\
\hline $\mathrm{CHO}$ routing (\%) & $22 \cdot 4$ & $2 \cdot 1$ & $17 \cdot 6-24 \cdot 5$ & $13 \cdot 7$ & $1 \cdot 3$ & $10 \cdot 8-15 \cdot 0$ \\
\hline Lipid routing (\%) & 3.4 & 0.3 & $2 \cdot 7-3 \cdot 8$ & $12 \cdot 1$ & $1 \cdot 1$ & $9 \cdot 5-13 \cdot 3$ \\
\hline
\end{tabular}

$\mathrm{CHO}$, carbohydrates.

The protein, $\mathrm{CHO}$ and lipid routings are the proportions of dietary protein, $\mathrm{CHO}$ and lipid $\mathrm{C}$ used for amino acid synthesis and consequently routed to $\mathrm{C}$ in tissue proteins, and the trophic step is the difference in $\delta^{13} \mathrm{C}$ between dietary and tissue proteins owing to isotopic fractionation along metabolic pathways (i.e. the coefficients $p, c, 1-p-c$ and TS of Equation (6), see the 'Methods' section). The protein routing and trophic step were assumed to be equal across the diets, whereas the $\mathrm{CHO}$ and lipid routings differed in rats fed the normal-fat or high-fat diet. 
routing was 22.4 (SD 2.1) \% and 13.7 (SD 1.3)\%, respectively (Table 3). Therefore, in rats fed the NF and HF diets, where dietary lipids contributed to 13 and $61 \%$ of $\mathrm{C}$ in non-protein sources $(\mathrm{CHO}+$ lipids), dietary lipids contributed to $13 \%$ and only $47 \%$ of non-protein $\mathrm{C}$ routed to tissue proteins (energy routing, see the 'Methods' section). It should be noted that, among the tissues studied, erythrocytes were outliers for all nutrient routing, with the highest value for protein routing and the lowest values for $\mathrm{CHO}$ and lipid routing (online Supplementary Table S2).
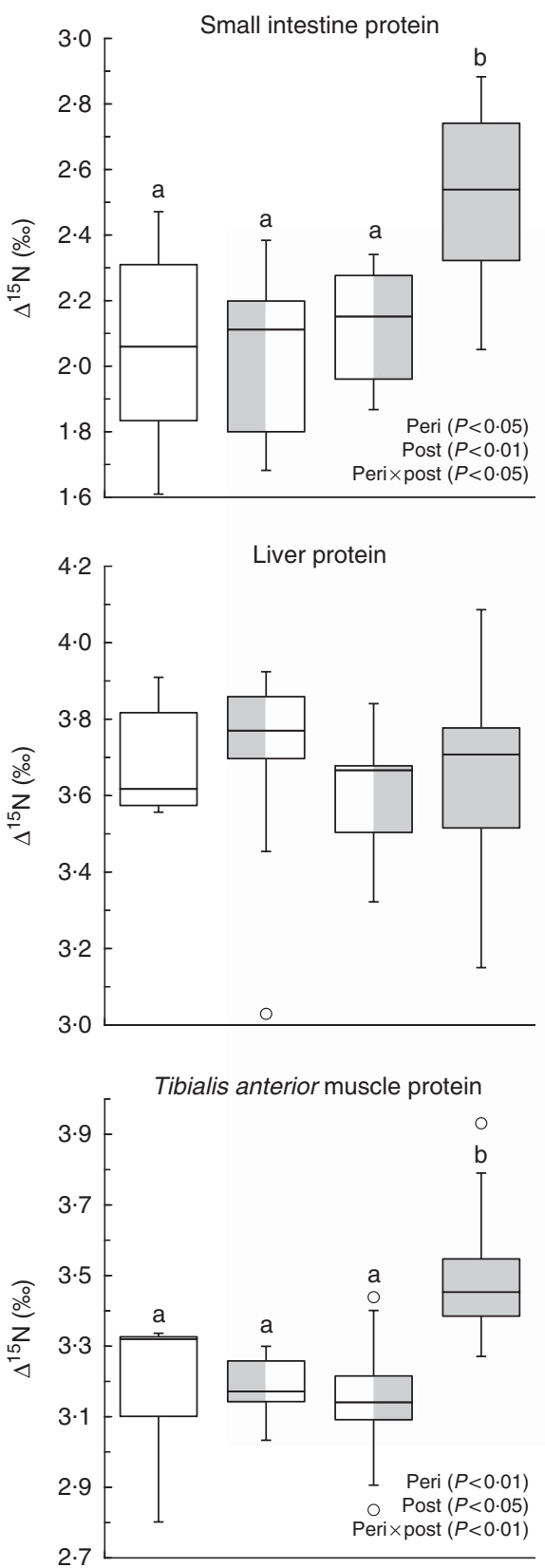

Natural abundances of stable nitrogen isotopes $\left(\Delta^{15} \mathrm{~N}\right)$ in tissue proteins and amino acid allocation between anabolic and catabolic pathways

Fig. 1 shows $\Delta^{15} \mathrm{~N}$ values in faeces and proteins of the small intestine, liver, tibialis anterior and gastrocnemius muscles, and adipose tissue. In adipose tissue proteins, $\Delta^{15} \mathrm{~N}$ values were up to $0.5 \%$ higher in rats fed the HF diet after weaning than in those never exposed to the HF diet (NF-HF and HF-HF $v$. NF-NF; $P<0.001$ and $P<0.05$, respectively), and also tended to
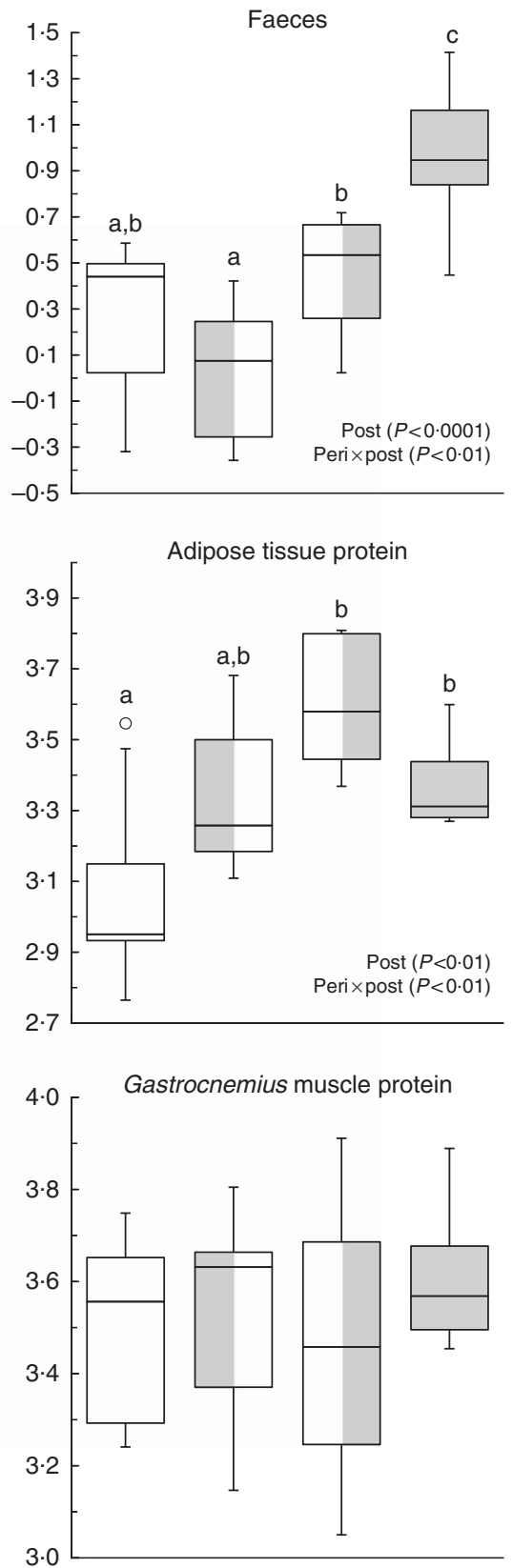

Fig. 1. Natural abundances of $\mathrm{N}$ stable isotopes in tissue proteins $\left(\Delta^{15} \mathrm{~N}, \%\right.$ ) in rats exposed to a normal-fat (NF) diet or a high-fat (HF) diet at different periods. Boxes represent the interquartile range (IQR, the difference between the 75th and the 25th percentiles), the line inside the box corresponds to the medians and 50th percentile and whiskers extend to maximum and minimum values or 1.5 times the IQR if outliers (O) exceed that distance. 追, NF-NF; 白, HF-NF; 白, NF-HF; 白, HF-HF. Peri, perinatal diet; post, post-weaning diet. ${ }^{a, b, c}$ Values with unlike letters were significantly different between groups $(P<0.05)$. Values concern the protein fraction of tissues except for faeces (bulk) that were only freeze-dried and homogenised before analysis. 
High-fat diet and protein metabolism

Table 4. Pearson's correlation coefficients of significant correlations between natural abundances of stable nitrogen isotopes in tissue proteins $\left(\Delta^{15} \mathrm{~N}\right)$ and body composition and metabolic parameters $\dagger$

\begin{tabular}{|c|c|c|c|c|c|c|}
\hline & \multicolumn{3}{|c|}{ Body composition } & \multicolumn{3}{|c|}{ Metabolic parameters } \\
\hline & Body weight & Fat mass & Lean mass & Glucose OGTT AUC & Feed efficiency & Liver PAE \\
\hline $\begin{array}{l}\text { Faeces } \Delta^{15} \mathrm{~N} \\
\text { Protein } \Delta^{15} \mathrm{~N}\end{array}$ & $0.42^{*}$ & $0.41^{*}$ & & $0.43^{\star}$ & $0.47^{\star \star}$ & \\
\hline Small intestine & $0.46^{\star \star}$ & $0.37^{*}$ & & & $0.46^{\star \star}$ & \\
\hline $\begin{array}{l}\text { Adipose tissue } \\
\text { muscle }\end{array}$ & $0.40^{\star}$ & $0.42^{*}$ & $0.45^{\star *}$ & & $0.42^{*}$ & \\
\hline Liver & & & & $-0.46^{\star \star}$ & $-0.40^{*}$ & $-0.56^{\star \star \star}$ \\
\hline
\end{tabular}

OGTT AUC, area under the concentration-time curve during oral glucose tolerance test; G, gastrocnemius; PAE, protein anabolism efficiency.

${ }^{\star} P<0.05,{ }^{* *} P<0.01,{ }^{* * *} P<0.001, n 28-32$.

† All correlations were significant at a false discovery rate of $15 \%$.

be $0.2 \%$ higher following perinatal exposure alone (HF-NF $v$. NF-NF; $P<0 \cdot 08)$. In faeces and proteins of the small intestine and tibialis anterior muscle, combined HF exposure during the perinatal and post-weaning periods (HF-HF) resulted in $0.7,0 \cdot 4$ and $0.3 \%$ higher $\Delta^{15} \mathrm{~N}$ values, respectively, compared with all the other conditions (all $P<0.05$ ). These diet-induced $\Delta^{15} \mathrm{~N}$ variations indicated diet-induced differences in $\mathrm{p}_{\mathrm{ox}}$, the AA allocation between catabolic and anabolic pathways, in the corresponding tissues. By contrast, $\Delta{ }^{15} \mathrm{~N}$ did not differ between the diet groups in proteins of the liver $(3.7$ (SD 0.2) \%o), heart $(4.9(\mathrm{sD} 0.3) \%$ ) , plasma $(4.6$ (SD 0.2$) \% o$ ), erythrocytes $(2.2$ $(\mathrm{SD} 0.1) \% 0$ ) and the gastrocnemius (3.5 ( $\mathrm{SD} 0.2) \% 0$ ), soleus $(4 \cdot 1(\mathrm{sD} 0 \cdot 2) \%$ ) and extensor digitorum longus muscles (3.7 (SD 0.2$) \%$ ). Detailed $\Delta^{15} \mathrm{~N}$ values are shown in the online Supplementary Table S1.

Pearson's correlation coefficients of the significant correlations seen between $\Delta^{15} \mathrm{~N}$ and body composition or metabolic parameters are listed in Table 4 . The $\Delta^{15} \mathrm{~N}$ values of intestinal proteins, faeces and adipose tissue proteins were all positively associated with body weight, fat mass and feed efficiency, and $\Delta^{15} \mathrm{~N}$ values of faeces were also positively associated with glucose OGTT AUC $(0.37 \leq r \leq 0.47)$. In contrast, the $\Delta^{15} \mathrm{~N}$ values of proteins in the gastrocnemius muscle were positively associated with lean mass $(r 0 \cdot 45)$, whereas the $\Delta^{15} \mathrm{~N}$ values of liver proteins were negatively associated with liver protein anabolism efficiency $(r-0.56)$, glucose OGTT AUC $(r-0.46)$ and feed efficiency $(r-0 \cdot 40)$.

\section{Discussion}

During this animal study performed in a carefully controlled dietary environment, we were able to reveal some of the tissuespecific changes that affect protein and AA metabolism in response to $\mathrm{HF}$ feeding depending on the exposure window (perinatal and/or post-weaning). This was made possible by the use of a new isotopic approach that consisted in measuring the natural abundances of ${ }^{13} \mathrm{C}$ and ${ }^{15} \mathrm{~N}\left(\delta^{13} \mathrm{C}\right.$ and $\left.\delta^{15} \mathrm{~N}\right)$ in proteins from a large set of tissues. Using $\delta^{13} \mathrm{C}$, we were able to determine the contribution of each dietary macronutrient to AA renewal in the different tissues (i.e. nutrient routing), whereas the use of $\delta^{15} \mathrm{~N}$ enabled us to characterise the partitioning of AA between oxidation and protein synthesis pathways in the different tissues (i.e. $\mathrm{p}_{\mathrm{ox}}$, the proportion of tissue $\mathrm{AA}$ that are directed towards oxidation rather than used for protein synthesis). More specifically, our tissue protein $\delta^{13} \mathrm{C}$ measurements were analysed with a new routing model, which allowed quantitative estimation of nutrient routing for each studied diet, whereas our tissue protein $\delta^{15} \mathrm{~N}$ measurements were interpreted in the light of previous modelling ${ }^{(31)}$ and experimental ${ }^{(29)}$ results, which allowed qualitative estimation of the diet-induced differences in $\mathrm{p}_{\mathrm{ox}}$. A necessary condition to validate our interpretation of these $\delta^{13} \mathrm{C}$ and $\delta^{15} \mathrm{~N}$ data was that sufficient time had elapsed since the last diet-shift - that is, $\delta^{13} \mathrm{C}$ and $\delta^{15} \mathrm{~N}$ were no longer evolving but had reached their final equilibrium values with the post-weaning diet. In our study, nearly all body proteins had very likely reached their isotopic equilibrium at the end of the 100-d post-weaning period. Indeed, according to findings available in the literature, the times necessary to reach $\delta^{13} \mathrm{C}$ and $\delta^{15} \mathrm{~N}$ equilibrium in rat tissues range from less than or about $50 \mathrm{~d}$ in small intestine, liver and plasma to about $100 \mathrm{~d}$ in muscles ${ }^{(45,54-57)}$. The only exception was erythrocytes, for which a longer period (130-180 d) has been reported to be necessary to achieve isotopic equilibrium ${ }^{(31,55)}$

\section{Dietary macronutrient use for amino acid synthesis}

Because the three dietary macronutrients generally differ in terms of their $\delta^{13} \mathrm{C}$ values and can all be used for AA synthesis, $\delta^{13} \mathrm{C}$ in tissue proteins reflects macronutrient use for AA synthesis and subsequent routing to proteins, the extent of which may vary in line with the macronutrient composition of the diet ${ }^{(43,46,56)}$. Compiled data from studies involving a wide variety of dietary conditions suggest a contribution of about $75 \%$ of dietary protein to $\mathrm{C}$ in tissue proteins ${ }^{(43,44,56)}$ with, for instance, protein routing of $74 \%$ to bone collagen under a broad range of dietary compositions except for diets markedly deficient or excessive in protein ${ }^{(43)}$. Here, protein routing was estimated to reach 74.2 (SD 2.4) \% across all tissues, which is consistent with the mean values and minor inter-tissue variations recorded by the studies in the literature ${ }^{(43,44,49,56)}$. Furthermore, taking advantage of the different $\delta^{13} \mathrm{C}$ signatures of dietary $\mathrm{CHO}$ and lipid, we were able to distinguish their respective routings for the first time. In the same way as for protein routing, we found few inter-tissue variations regarding the routing of $\mathrm{CHO}$ and lipid under each diet, although erythrocyte was an outlier with the lowest values for both $\mathrm{CHO}$ and lipid routing. This limited inter-tissue variability probably 
reflects the fact that almost all the tissues studied are reliant on a mix of energy fuels during the postprandial period and more on lipids during the post-absorptive period. The only exception is erythrocytes, which are strictly dependent on glucose to fuel their energy metabolism because they lack mitochondria. However, as erythrocytes do not synthesise protein, the lipid and $\mathrm{CHO}$ routing calculated in erythrocytes will tend to reflect the mixed utilisation of lipid and $\mathrm{CHO}$ in bone marrow. Notwithstanding this, and as discussed above, our routing estimates for erythrocytes may have been partially biased because erythrocytes was the tissue most likely to be influenced by incomplete isotopic turnover.

Interestingly, we found that during NF feeding lipid contributed to the routing of non-protein nutrients in proportion with their dietary occurrence in non-protein nutrients (13\%), whereas during $\mathrm{HF}$ feeding lipid contributed more to the routing of nonprotein nutrients $(47 \%)$ but less than in proportion with their dietary occurrence in non-protein nutrients (67\%). One likely explanation is that dietary lipids cannot enter all the pathways of non-protein $\mathrm{C}$ routing to $\mathrm{AA}^{(43)}$ : some $\mathrm{AA}$ (Ala, Ser, Cys and to a lesser extent Gly) are synthesised from $3 \mathrm{C}$ precursors, which are mostly produced during glycolysis, whereas others (Asx, Glx, Pro and Arg) are derived from 4 and $5 \mathrm{C}$ precursors produced during the tricarboxylic acid cycle that is fuelled by both glucose and fatty acids via acetyl-CoA. Therefore, an increase in the proportion of lipid in the diet may lead to a proportional rise in lipid-derived C in Asx, Glx Pro and Arg, but not in Ala, Ser, Cys and Gly. In this context, HF-diet-induced changes to the routing of dietary $\mathrm{CHO}$ and lipid merely reflected differences in their dietary availability and possible access to the metabolic pathways of AA synthesis, rather than being the consequence of marked changes to the enzymatic activities that occur during adaptation to a new dietary environment.

In our young adult rats, the routing of dietary lipids to tissue proteins thus increased in line with recent, post-weaning, HF exposure, whereas we found no significant effect of earlier, perinatal, HF exposure. This suggests that perinatal HF exposure has no lasting effect on dietary nutrient routing to tissue proteins in later life. It does not preclude the possibility that HF exposure might have affected nutrient routing during the perinatal period in the same way as it did during the post-weaning period, but this could not be traced in tissue protein $\delta^{13} \mathrm{C}$ at the end of the 100-d post-weaning period. After such a time delay, routing effects limited to the perinatal period are no longer detectable. As discussed above, $100 \mathrm{~d}$ were indeed sufficient to reach isotopic equilibrium with the post-weaning diet in nearly all tissues by complete isotopic turnover since the perinatal period $^{(45,54-57)}$, so that the isotopic footprints of earlier effects on nutrient routing had been cleared.

\section{Tissue amino acid allocation between anabolic and} catabolic pathways

Although all dietary macronutrients contain C, only dietary proteins contain $\mathrm{N}$ and are the almost exclusive sources of the $\mathrm{N}$ found in tissue proteins. Because bioaccumulation of the heavy isotope ${ }^{15} \mathrm{~N}$ is known to occur, our tissue protein $\delta^{15} \mathrm{~N}$ measurements were expressed as $\Delta^{15} \mathrm{~N}$ in order to represent ${ }^{15} \mathrm{~N}$ enrichment over dietary protein. Our tissue protein $\Delta^{15} \mathrm{~N}$ measurements ranged from 2 to $5 \%$; these values were in line with the few findings available in the literature on rodents ${ }^{(30,31,45,54-56,58)}$. Furthermore, the diet-induced $\Delta^{15} \mathrm{~N}$ differences that we observed in some tissue proteins point to diet-induced differences in $\mathrm{p}_{\mathrm{ox}}$, the relative proportion of AA entering the tissue that is directed toward catabolism. Indeed, according to our previous experimental and modelling results ${ }^{(29,31)}$, a higher $\delta^{15} \mathrm{~N}$ difference between tissue and dietary proteins (i.e. a higher $\Delta^{15} \mathrm{~N}$ ) indicates a higher $\mathrm{p}_{\mathrm{ox}}$ in all tissues except the muscle, where it indicates a lower $\mathrm{p}_{\mathrm{ox}}$. Although we found that HF feeding systematically favoured AA synthesis from dietary fat in all tissues, we saw no associated changes in $\Delta^{15} \mathrm{~N}$, and thus in $\mathrm{p}_{\mathrm{ox}}$, in most of the tissues studied (seven out of eleven), namely three skeletal muscles (gastrocnemius, soleus and extensor digitorum longus), the heart, plasma, erythrocytes and liver. In contrast, the present results suggest that HF nutrition affected $\mathrm{p}_{\mathrm{ox}}$ in three other tissues, namely the small intestine (and consequently faeces), tibialis anterior muscle and adipose tissue. In the protein of these three tissues, we observed an HF-induced increase in $\Delta^{15} \mathrm{~N}$, but according to different patterns: prolonged HF exposure covering both the perinatal and post-weaning periods was required for the small intestine and tibialis anterior muscle, whereas for adipose tissue post-weaning exposure alone was sufficient, and perinatal exposure alone tended to be sufficient, to attain a significant effect. According to our previous works ${ }^{(29,31)}$, the HF-induced increase in protein $\Delta^{15} \mathrm{~N}$ indicated with confidence a more preferential catabolic use of $\mathrm{AA}$ (i.e. a higher $\mathrm{p}_{\mathrm{ox}}$ ) in the small intestine and the opposite (i.e. a lower $\mathrm{p}_{\mathrm{ox}}$ ) in the tibialis anterior. In contrast, as adipose tissue had not been considered in our previous works, a metabolic interpretation of its increase in $\Delta^{15} \mathrm{~N}$ levels was not straightforward. Because a compelling body of evidence supports the reduced expression and activity of enzymes involved in branched-chain AA oxidation (i.e. branched-chain aminotransferase and $\alpha$-ketoacid dehydrogenase) in adipose tissue in the context of both genetic and diet-induced obesity and insulin resistance ${ }^{(18,59,60)}$, higher $\Delta^{15} \mathrm{~N}$ levels likely indicate less preferential catabolic orientation of AA metabolism in adipose tissue (i.e. a lower $\mathrm{p}_{\mathrm{ox}}$ ), as is the case in muscle.

Regarding the tibialis anterior muscle, the rise in its $\Delta^{15} \mathrm{~N}$ level after prolonged HF nutrition - during both the perinatal and post-weaning periods - indicated a lower $\mathrm{p}_{\mathrm{ox}}$ and thus a stronger preferential anabolic orientation of its AA metabolism. Higher protein synthesis in some muscles was likely in the specific context of our study, as it encompassed the early phase of the development of obesity where the gain in fat mass is accompanied by a concomitant gain in lean and muscle masses, as observed here and reported elsewhere ${ }^{(61)}$. During this early phase, the gain in muscle mass has been shown to be associated with an increased fractional protein synthesis rate in the tibialis anterior muscle but not in the soleus muscle ${ }^{(61)}$, which is exactly in line with our observation of a $\Delta^{15} \mathrm{~N}$ increase in the former but not in the latter. Furthermore, limited evidence has suggested that branched-chain $\alpha$-ketoacid dehydrogenase activity, the rate-limiting step in branched-chain AA oxidation, is reduced in the muscle of obese rodents ${ }^{(62)}$. The rise in $\Delta^{15} \mathrm{~N}$ levels in the protein of the tibialis anterior muscle after prolonged HF exposure could therefore result from an increased 
anabolic use and/or a decreased catabolic use of AA in this tissue. Such a reduction in the relative allocation of AA to oxidation in specific muscles may contribute to the elevation of circulating levels of branched-chain AA and some other AA during obesity and insulin resistance.

Regarding the small intestine, its increased $\Delta^{15} \mathrm{~N}$ levels after prolonged HF nutrition - during both the perinatal and postweaning periods - indicated a higher $\mathrm{p}_{\mathrm{ox}}$ and thus a weaker preferential anabolic orientation of its AA metabolism. There is a paucity of data regarding the effect of HF feeding on intestinal protein metabolism. In a mouse model of obesity, some cellular changes have recently been observed in the small intestine epithelium that might impair the synthesis of proteins, and particularly those involved in the gut barrier function ${ }^{(63)}$. Interestingly, the similarity between the $\Delta^{15} \mathrm{~N}$ profiles of proteins in the small intestine and faeces reflected the important contribution of enterocyte shedding and intestinal mucins to the $\mathrm{N}$ flux entering the colon, and suggests that faeces might be considered as a more accessible proxy for the small intestine when seeking to determine isotopic biomarkers of diet-induced metabolic orientations.

Apart from the above-mentioned effects of the dietary group on $\Delta^{15} \mathrm{~N}$ values in some tissues, we found significant correlations between the $\Delta^{15} \mathrm{~N}$ values in other tissues and certain indicators of their protein anabolism efficiency, which depends on their efficiency of AA anabolic use for protein synthesis $v$. catabolic use for oxidation $\left(\mathrm{p}_{\mathrm{ox}}\right)$. In particular, $\Delta^{15} \mathrm{~N}$ levels in liver protein were negatively correlated with liver protein anabolism efficiency, and $\Delta^{15} \mathrm{~N}$ in gastrocnemius muscle protein was positively correlated with lean mass, which is known to increase in line with muscle mass and muscle protein anabolism efficiency. Such inverse associations between protein $\Delta^{15} \mathrm{~N}$ and efficiency of AA anabolic ( $v$. catabolic) use in liver and muscle were in line with our previous model predictions, and resulted from the opposite signs of isotopic fractionation associated with AA catabolism in liver and muscle ${ }^{(31)}$. The negative association between liver protein $\Delta^{15} \mathrm{~N}$ and anabolism efficiency had previously been confirmed experimentally in a metabolic tracer study in ruminants, where we have shown that the $\Delta^{15} \mathrm{~N}$ of liver-synthesised plasma proteins increases linearly with liver AA oxidation and urea production ${ }^{(29)}$, but the present study is the first to have demonstrated a positive association between muscle protein $\Delta^{15} \mathrm{~N}$ levels and lean mass. Our results therefore indicate that in different splanchnic and peripheral tissues $\Delta^{15} \mathrm{~N}$ could be used as a valuable biomarker of protein anabolism in the considered tissue.

\section{Strengths and limitations of the present study}

By using a new isotopic approach consisting in analysing the natural abundances of ${ }^{13} \mathrm{C}$ and ${ }^{15} \mathrm{~N}$ in tissue proteins, we were able to unveil the effects of HF feeding on the nutrient routing to tissue AA and on the relative metabolic use of tissue AA for oxidation $v$. protein synthesis $\left(\mathrm{p}_{\mathrm{ox}}\right)$, respectively. The change in lipid content between diets was confounded with a change in $\mathrm{CHO}$ content and profile, so that the HF diet was enriched in fat but also in sucrose compared with the NF diet, a classic dietary pattern for mimicking the contrasted profiles of energy intake in humans while being able to induce obesity and insulin resistance with the fat- and sucrose-enriched diet ${ }^{(64,65)}$. During our nutrient routing estimation by ${ }^{13} \mathrm{C}$ data analysis, for identifiability reasons, the protein routing and trophic steps were assumed to be equal across the diets despite their different compositions. An identical protein routing between diets is very likely given their identical protein content, inasmuch as protein routing has been found notably stable - about $75 \%$ - under a broad range of dietary compositions, and our present estimate for protein routing was indeed strictly in line with these previous estimates ${ }^{(43,44,49,56)}$. In contrast, an identical trophic step between diets of different $\mathrm{CHO}$ and lipid contents and profiles is a more questionable simplifying assumption that could have biased our estimates for the $\mathrm{CHO}$ and lipid routings, but probably only marginally. Indeed, numerically, our estimate for trophic step only marginally affected the $\mathrm{CHO}$ and lipid routings calculated in Equations (7) and (8) (e.g. a $25 \%$ variation in the trophic step value used in these equations resulted in an absolute difference of $<1 \%$ in the calculated $\mathrm{CHO}$ and lipid routing values). Our routing estimates for erythrocytes may have also been biased because of incomplete isotopic turnover in this tissue, but only marginally as the erythrocytes isotopic values should have reached $80-90 \%$ of their final equilibrium values at $100 \mathrm{~d}$, when considering that $130-180 \mathrm{~d}$ are required for complete isotopic turnover in this tissue $\mathrm{e}^{(31,55)}$. A last limitation relates to the interpretation of the diet-induced $\Delta^{15} \mathrm{~N}$ differences in terms of $p_{o x}$, which was based on previous modelling and experimental findings rather than by a devoted modelling analysis of the present data set, because the data set at hand was insufficient for being analysed by such a complex multicompartmental model as the one we previously developed ${ }^{(31)}$.

In conclusion, our results show that HF feeding increases both dietary fat deposition in adipose tissues and dietary fat routing to the protein of all tissues via AA synthesis from tricarboxylic acid cycle intermediates. In addition, our $\Delta^{15} \mathrm{~N}$ data also support HF-induced changes to the relative orientation of AA metabolism towards oxidation $v$. protein synthesis in three tissues, with more oxidation in the small intestine but less in the tibialis anterior muscle and adipose tissue.

\section{Acknowledgements}

The authors thank N. Khodorova for her technical assistance in isotopic measurements, and Dr M. Sebilo and V. Vaury (UMR 7618 BIOEMCO, Université Pierre et Marie Curie, Paris, France) for supplying the internal standard for isotopic measurements.

O. L. M. was supported by a PhD grant from the doctoral school ABIES (ED 581).

The authors' contributions are as follows: H. F. and J.-F. H. formulated the research question in this ancillary study derived from a larger experiment designed by S. P. and D. Z. S. P. conducted the animal protocol and tissue sampling, O. L. M. conducted the tissue preparation and isotopic analysis and $\mathrm{H}$. F. and N. P. conducted the isotopic data modelling and analysis in collaboration with J.-F. H. and F. M. H. F., J.-F. H., O. L. M. and F. M. analysed and interpreted the data. All authors were involved in the preparation of the manuscript and approved the final manuscript. H. F. had primary responsibility for the final content.

The authors declare that there are no conflicts of interest. 


\section{Supplementary material}

For supplementary material/s referred to in this article, please visit https://doi.org/10.1017/S0007114518000326

\section{References}

1. Astrup A, Dyerberg J, Selleck M, et al. (2008) Nutrition transition and its relationship to the development of obesity and related chronic diseases. Obes Rev $9,48-52$.

2. Danaei G, Lu Y, Singh GM, et al. (2014) Cardiovascular disease, chronic kidney disease, and diabetes mortality burden of cardiometabolic risk factors from 1980 to 2010: a comparative risk assessment. Lancet Diabetes Endo 2, 634-647.

3. Blundell JE, Stubbs RJ, Golding C, et al. (2005) Resistance and susceptibility to weight gain: individual variability in response to a high-fat diet. Physiol Behav 86, 614-622.

4. Levin EB (2007) Why some of us get fat and what we can do about it. J Physiol-London 583, 425-430.

5. Stoger R (2008) The thrifty epigenotype: an acquired and heritable predisposition for obesity and diabetes? Bioessays 30, 156-166.

6. Azzout-Marniche D, Chaumontet C, Nadkarni NA, et al. (2014) Food intake and energy expenditure are increased in high-fatsensitive but not in high-carbohydrate-sensitive obesityprone rats. Am J Physiol-Reg I 307, R299-R309.

7. Levin BE, DunnMeynell AA, Balkan B, et al. (1997) Selective breeding for diet-induced obesity and resistance in SpragueDawley rats. Am J Physiol 273, R725-R730.

8. Bray GA \& Popkin BM (1998) Dietary fat intake does affect obesity!. Am J Clin Nutr 68, 1157-1173.

9. Poudyal H, Panchal SK, Ward LC, et al. (2012) Chronic highcarbohydrate, high-fat feeding in rats induces reversible metabolic, cardiovascular, and liver changes. Am J Physiol Endocrinol Metab 302, E1472-E1482.

10. Hardy OT, Czech MP \& Corvera S (2012) What causes the insulin resistance underlying obesity? Curr Opin Endocrinol Diabetes Obes 19, 81-87.

11. Nagao M, Asai A, Sugihara H, et al. (2015) Fat intake and the development of type 2 diabetes. Endocr J 62, 561-572.

12. Ainge H, Thompson C, Ozanne SE, et al. (2011) A systematic review on animal models of maternal high fat feeding and offspring glycaemic control. Int J Obesity 35, 325-335.

13. Desai M, Jellyman JK, Han G, et al. (2014) Maternal obesity and high-fat diet program offspring metabolic syndrome. Am J Obstet Gynecol 211, 237.e231-237.e213.

14. Li M, Sloboda DM \& Vickers MH (2011) Maternal obesity and developmental programming of metabolic disorders in offspring: evidence from animal models. Exp Diabetes Res 2011, 592408.

15. Guillet C, Masgrau A \& Boirie Y (2011) Is protein metabolism changed with obesity? Curr Opin Clin Nutr 14, 89-92.

16. Katsanos CS \& Mandarino LJ (2011) Protein metabolism in human obesity: a shift in focus from whole-body to skeletal muscle. Obesity 19, 469-475.

17. Lotta LA, Scott RA, Sharp SJ, et al. (2016) Genetic predisposition to an impaired metabolism of the branched-chain amino acids and risk of type 2 diabetes: a Mendelian randomisation analysis. Plos Med 13, e1002179.

18. Lynch CJ \& Adams SH (2014) Branched-chain amino acids in metabolic signalling and insulin resistance. Nat Rev Endocrinol 10, 723-736.

19. Newgard CB, An J, Bain JR, et al. (2009) A branched-chain amino acid-related metabolic signature that differentiates obese and lean humans and contributes to insulin resistance. Cell Metab 9, 311-326.
20. Tulipani S, Palau-Rodriguez M, Alonso AM, et al. (2016) Biomarkers of morbid obesity and prediabetes by metabolomic profiling of human discordant phenotypes. Clin Chim Acta 463, 53-61.

21. Wang TJ, Larson MG, Vasan RS, et al. (2011) Metabolite profiles and the risk of developing diabetes. Nat Med 17, 448-U483.

22. Yamakado M, Nagao K, Imaizumi A, et al. (2015) Plasma free amino acid profiles predict four-year risk of developing diabetes, metabolic syndrome, dyslipidemia, and hypertension in Japanese population. Sci Rep 5, 11918.

23. She PX, Van Horn C, Reid T, et al. (2007) Obesity-related elevations in plasma leucine are associated with alterations in enzymes involved in branched-chain amino acid metabolism. Am J Physiol Endocrinol Metab 293, E1552-E1563.

24. Chevalier S, Marliss EB, Morais JA, et al. (2005) Whole-body protein anabolic response is resistant to the action of insulin in obese women. Am J Clin Nutr 82, 355-365.

25. Denne SC, Brechtel G, Johnson A, et al. (1995) Skeletalmuscle proteolysis is reduced in noninsulin-dependent diabetes-mellitus and is unaltered by euglycemic hyperinsulinemia or intensive insulin therapy. J Clin Endocrinol Metab 80, 2371-2377.

26. Gougeon R, Morais JA, Chevalier S, et al. (2008) Determinants of whole-body protein metabolism in subjects with and without type 2 diabetes. Diabetes Care 31, 128-133.

27. Patterson BW, Horowitz JF, Wu GY, et al. (2002) Regional muscle and adipose tissue amino acid metabolism in lean and obese women. Am J Physiol Endocrinol Metab 282, E931-E936.

28. Fouillet H, Bos C, Gaudichon C, et al. (2002) Approaches to quantifying protein metabolism in response to nutrient ingestion. J Nutr 132, 3208s-3218s.

29. Cantalapiedra-Hijar G, Ortigues-Marty I, Sepchat B, et al. (2015) Diet - animal fractionation of nitrogen stable isotopes reflects the efficiency of nitrogen assimilation in ruminants. Br J Nutr 113, 1158-1169.

30. Poupin N, Bos C, Mariotti F, et al. (2011) The nature of the dietary protein impacts the tissue-to-diet $15 \mathrm{~N}$ discrimination factors in laboratory rats. PLOS ONE 6, e28046.

31. Poupin N, Mariotti F, Huneau JF, et al. (2014) Natural isotopic signatures of variations in body nitrogen fluxes: a compartmental model analysis. PLoS Computat Biol 10, e1003865.

32. O'Brien DM (2015) Stable isotope ratios as biomarkers of diet for health research. Ann Rev Nutr 35, 565-594.

33. Martinez del Rio C \& Wolf BO (2005) Mass-balance models for animal isotopic ecology. In Physiological and Ecological Adaptations to Feeding in Vertebrates, pp. 141-174 [JM Starck and T Wang, editors]. Enfield, NH: Science Publishers, Inc.

34. Fuller BT, Fuller JL, Sage NE, et al. (2004) Nitrogen balance and $\delta 15 \mathrm{~N}$ : why you're not what you eat during pregnancy. Rapid Commun Mass Spectrom 18, 2889-2896.

35. Fuller BT, Fuller JL, Sage NE, et al. (2005) Nitrogen balance and delta N-15: why you're not what you eat during nutritional stress. Rapid Commun Mass Spectrom 19, 2497-2506.

36. Hatch KA, Crawford MA, Kunz AW, et al. (2006) An objective means of diagnosing anorexia nervosa and bulimia nervosa using $15 \mathrm{~N} / 14 \mathrm{~N}$ and $13 \mathrm{C} / 12 \mathrm{C}$ ratios in hair. Rapid Commun Mass Spectrom 20, 3367-3373.

37. Mekota AM, Grupe G, Ufer S, et al. (2006) Serial analysis of stable nitrogen and carbon isotopes in hair: monitoring starvation and recovery phases of patients suffering from anorexia nervosa. Rapid Commun Mass Spectrom 20, 1604-1610.

38. Petzke KJ, Feist T, Fleig WE, et al. (2006) Nitrogen isotopic composition in hair protein is different in liver cirrhotic patients. Rapid Commun Mass Spectrom 20, 2973-2978. 
39. Cheng L, Sheahan A, Gibbs S, et al. (2013) Technical note: nitrogen isotopic fractionation can be used to predict nitrogen-use efficiency in dairy cows fed temperate pasture. J Anim Sci 91, 5785-5788.

40. Gaye-Siessegger J, Focken U, Abel H, et al. (2004) Individual protein balance strongly influences $\delta 15 \mathrm{~N}$ and $\delta 13 \mathrm{C}$ values in Nile tilapia, Oreochromis niloticus. Naturwissenschaften 91, 90-93.

41. Robbins CT, Felicetti LA \& Sponheimer M (2005) The effect of dietary protein quality on nitrogen isotope discrimination in mammals and birds. Oecologia 144, 534-540.

42. McCutchan JH, Lewis WM, Kendall C, et al. (2003) Variation in trophic shift for stable isotope ratios of carbon, nitrogen, and sulfur. Oikos 102, 378-390.

43. Fernandes R, Nadeau M-J \& Grootes PM (2012) Macronutrientbased model for dietary carbon routing in bone collagen and bioapatite. Archaeol Anthropol Sci 4, 291-301.

44. Kurle CM, Koch PL, Tershy BR, et al. (2014) The effects of sex, tissue type, and dietary components on stable isotope discrimination factors (Delta13C and Delta15N) in mammalian omnivores. Isotopes Environ Health Stud 50, 307-321.

45. MacAvoy SE, Macko SA \& Arneson LS (2005) Growth versus metabolic tissue replacement in mouse tissues determined by stable carbon and nitrogen isotope analysis. Can J Zool 83, 631-641.

46. Wolf N, Newsome SD, Peters J, et al. (2015) Variability in the routing of dietary proteins and lipids to consumer tissues influences tissue-specific isotopic discrimination. Rapid Commun Mass Spectrom 29, 1448-1456.

47. Butz DE, Casperson SL \& Whigham LD (2014) The emerging role of carbon isotope ratio determination in health research and medical diagnostics. J Anal Atom Spectrom 29, 594-605.

48. Hatch KA, Sacksteder KA, Treichel IW, et al. (1995) Early Detection of catabolic state via change in C-13/C-12 ratios of blood proteins. Biochem Bioph Res Commun 212, 719-726.

49. Hobbie EA (2017) Dietary protein content and tissue type control C-13 discrimination in mammals: an analytical approach. Rapid Commun Mass Spectrom 31, 639-648.

50. Zalko D, Canlet C, Tremblay-Franco M, et al. (2017) Combined effects of perinatal exposure to bisphenol A and high fat diet in rats. 9th Copenhagen Workshop on Endocrine Disrupters - COW2017, 2-5 May 2017, Copenhagen, Denmark.

51. Reeves PG, Nielsen FH \& Fahey GC Jr (1993) AIN-93 purified diets for laboratory rodents: final report of the American Institute of Nutrition ad hoc writing committee on the reformulation of the AIN-76A rodent diet. J Nutr 123, 1939-1951.
52. Dell RB, Holleran S \& Ramakrishnan R (2003) Sample size determination (vol 43, pg 207, 2002). ILAR J 44, 239-239.

53. Benjamini Y \& Hochberg Y (1995) Controlling the false discovery rate: a practical and powerful approach to multiple testing. J Roy Statist Soc Ser B (Methodological) 57, 289-300.

54. Arneson LS \& MacAvoy SE (2005) Carbon, nitrogen, and sulfur diet-tissue discrimination in mouse tissues. Can J Zool 83 , 989-995.

55. Kurle CM (2009) Interpreting temporal variation in omnivore foraging ecology via stable isotope modelling. Funct Ecology 23, 733-744.

56. MacAvoy SE, Arneson LS \& Bassett E (2006) Correlation of metabolism with tissue carbon and nitrogen turnover rate in small mammals. Oecologia 150, 190-201.

57. Kraeer K, Arneson LS \& MacAvoy SE (2014) The intraspecies relationship between tissue turnover and metabolic rate in rats. Ecol Res 29, 937-947.

58. Yoneyama T, Ohta Y \& Ohtani T (1983) Variations of natural $13 \mathrm{C}$ and $15 \mathrm{~N}$ abundances in the rat tissues and their correlation. Radioisotopes 32, 330.

59. Estrada-Alcalde I, Tenorio-Guzman MR, Tovar AR, et al. (2017) Metabolic fate of branched-chain amino acids during adipogenesis, in adipocytes from obese mice and $\mathrm{C} 2 \mathrm{C} 12$ myotubes. J Cell Biochem 118, 808-818.

60. Polakof S, Rémond D, David J, et al. (2017) Time-course changes in circulating branched-chain amino acid levels and metabolism in obese Yucatan minipig. Nutrition (In the Press).

61. Masgrau A, Mishellany-Dutour A, Murakami H, et al. (2012) Time-course changes of muscle protein synthesis associated with obesity-induced lipotoxicity. J Physiol 590, 5199-5210.

62. Adams SH (2011) Emerging perspectives on essential amino acid metabolism in obesity and the insulin-resistant state. $A d v$ Nutr 2, 445-456.

63. Nakadate K, Motojima K, Hirakawa T, et al. (2016) Progressive depletion of rough endoplasmic Reticulum in epithelial cells of the small intestine in monosodium glutamate mice model of obesity. Biomed Res Int 2016, 5251738.

64. Yang ZH, Miyahara H, Takeo J, et al. (2012) Diet high in fat and sucrose induces rapid onset of obesity-related metabolic syndrome partly through rapid response of genes involved in lipogenesis, insulin signalling and inflammation in mice. Diabetol Metab Syndr $\mathbf{4}, 32$.

65. Wong SK, Chin KY, Suhaimi FH, et al. (2016) Animal models of metabolic syndrome: a review. Nutr Metab (Lond) 13, 65. 